DOI: https://doi.org/10.47405/mjssh.v6i10.1117

\begin{tabular}{|c|c|}
\hline & Malaysian Journal of Social Sciences and Humanities (MJSSH) \\
\hline Malaysian Journal of & Volume 6, Issue 10, October 2021 \\
\hline (MJ-SSH) & e-ISSN : 2504-8562 \\
\hline & $\begin{array}{l}\text { Journal home page: } \\
\text { www.msocialsciences.com }\end{array}$ \\
\hline
\end{tabular}

\title{
Penggunaan Kaedah Permainan, Buku Nombor dan Lembaran Kerja dalam Pembelajaran Matematik Awal Kanak-kanak
}

\author{
Connie Cassy Ompok ${ }^{1}$ \\ 1Faculty of Psychology and Education, Universiti Malaysia Sabah (UMS), Malaysia \\ Correspondence: Connie Cassy Ompok (connieompok@ums.edu.my)
}

\begin{abstract}
Abstrak
Menyediakan kanak-kanak untuk pendidikan matematik awal adalah penting. Tujuan kajian ini adalah untuk mengenal pasti tahap pencapaian matematik awal, mengenal pasti dan membandingkan kesan tiga kaedah mengajar (permainan, buku nombor dan lembaran kerja) terhadap pencapaian matematik awal dalam kalangan kanak-kanak prasekolah di daerah Tuaran, Sabah. Instrumen yang digunakan dalam kajian ini adalah Ujian Pencapaian Matematik Awal (UPMA) yang telah diadaptasi daripada Ginsburg dan Baroody (2003) mengikut Kurikulum Standard Prasekolah Kebangsaan. Seramai 1108 orang kanak-kanak prasekolah kebangsaan di daerah Tuaran, Sabah terlibat dalam kajian yang menggunakan kaedah kuasi eksperimen multi lokasi. Responden kajian terdiri daripada kanak-kanak prasekolah yang berumur $4+$ dan $5+.382$ orang kanak-kanak mengikuti kaedah permainan, 349 orang kanak-kanak mengikuti kaedah buku nombor dan 377 orang kanak-kanak mengikuti kaedah lembaran kerja. Kanak-kanak prasekolah menduduki ujian pra, seterusnya adalah program intervensi selama 13 minggu dan diakhiri dengan ujian pasca. Statistik deskriptif dan statistik inferen (ujian-t bebas, ANOVA satu hala dan ANCOVA) menggunakan SPSS versi-21 dengan mengambil kira markah ujian pra sebagai kovariat digunakan dalam kajian ini. Dapatan kajian menunjukkan terdapat perbezaan min markah yang signifikan dalam pencapaian matematik awal mengikut kaedah mengajar yang berbeza. Kaedah permainan menyumbang secara signifikan terhadap pencapaian matematik awal berbanding dengan kaedah buku nombor dan lembaran kerja.
\end{abstract}

Kata kunci: permainan, buku nombor, lembaran kerja, kanak-kanak, matematik awal

\section{The Use of Games, Number Books and Worksheet in Children Learning Early Mathematics}

\begin{abstract}
Preparing young children for Mathematics education is garnering much attention in the field of early childhood education. Factors have been examined in efforts to determine the effect on early Mathematics achievement. The purpose of this study was to identify the level of early Mathematics performance among national preschool children in Tuaran district, to identify and compare the effect of three teaching methods (games, number books and worksheets) towards early Mathematics achievement of preschool children. The instrument used in this research was the "Ujian Pencapaian Matematik Awal" (UPMA) which was adapted from Ginsburg and Baroody (2003) based on the National Standard Preschool Curriculum Malaysia 2010. This study was based on quantitative design that employed multi-site quasi-experiment consisting of 1108 preschool children aged $4+$ and 5+. 382 children participated in games, 349 children in number books and 377 children in worksheets method
\end{abstract}


respectively. The preschool children sat for pre-test, followed by 13 weeks of intervention program and ended with post-test. Descriptive statistics and inferential statistics (independent t-test, one-way ANOVA and two-way ANOVA repeated measure) with SPSS ver-21 by considering marks of pre-test as covariate were used. The findings showed that the level of the preschoolers' early Mathematics performance was average. Results also revealed that there was a significant difference in early Mathematics achievement due to different teaching methods. The use of games method contributed significantly to preschoolers' performance in early Mathematics compared to number books and worksheets methods.

Keywords: games, number books, worksheet, children, early mathematics

\section{Pengenalan}

Guru dan penyelidik perlu meningkatkan pengajaran Matematik yang berkualiti tinggi dengan memberi peluang kepada kanak-kanak menceburi bidang STEM (Lubinski, 2010). Perkara ini disebabkan, kanakkanak cenderung terlepas peluang untuk mempelajari kemahiran penting kerana pengetahuan asas yang lemah (Jordan, Kaplan, Ramineni \& Locuniak, 2009). Masyarakat juga perlu menyediakan pengalaman pendidikan mata pelajaran Matematik kanak-kanak untuk keperluan masa hadapan mereka (Smith, 2006). Selaras dengan kenyataan Lubinski (2010), Jordan et al. (2009) dan Smith (2006), program intervensi diperlukan untuk kanak-kanak. Sokongan ini adalah untuk mengelak daripada kegagalan yang berulang (Jordan et al., 2009). Antara contoh program intervensi yang dijalankan di luar negara adalah Building Blocks (Clements et al., 2011), Big Math for Little Kids (Greenes et al., 2004) dan Count Me In Too Indigenous (Report on the Count Me In Too Indigenous Project, 2002). Program intervensi mata pelajaran Matematik berpotensi meningkatkan pencapaian kanak-kanak tetapi program seperti ini belum banyak dijalankan untuk kanak-kanak di dalam negara.

Pemikiran Matematik menyumbang kepada kebolehan kanak-kanak untuk mengira, berkomunikasi dan berfikir secara praktikal tentang dunia dalam bidang Sains dan Teknologi (Pound, 2008). Menurut Ginsburg (1975), pengetahuan tidak formal berkembang semasa kanak-kanak meneroka persekitaran semulajadi dan kebolehan mereka ditingkatkan melalui pengajaran dan pembelajaran (Ramani \& Siegler, 2008; Baroody, Eiland \& Thompson, 2009). Peluang pengajaran dan pembelajaran dalam mata pelajaran Matematik adalah penting disebabkan kebolehan sedia ada kanak-kanak yang sedang berkembang. Kesedaran tentang keperluan ini menjadikan pendidikan mata pelajaran Matematik menjadi keutamaan negara (Hachey, 2013).

\section{Latar Belakang Kajian}

Masalah pencapaian yang rendah dalam mata pelajaran Matematik disumbangkan oleh beberapa isu seperti kurang perhatian dalam pengajaran dan pembelajaran, kanak-kanak tidak mempunyai peluang untuk membina kefahaman Matematik (Chard et al., 2008). Kajian Lee dan Ginsburg (2009) pula mendapati bahawa guru di Amerika Syarikat masih menganggap kanak-kanak tidak bersedia untuk belajar mata pelajaran Matematik. Malah, Clements dan Sarama (2011) menyatakan guru pendidikan awal kanak-kanak tidak memfokuskan kepada pengajaran mata pelajaran Matematik sebaliknya disepadukan dalam aktiviti lain seperti motor halus dan membaca. Pada pandangan penyelidik, persepsi sedemikian turut berlaku dalam senario pendidikan matematik awal di negara ini. Mata pelajaran Matematik penting dalam melakar sebuah kejayaan. Pendidikan awal kanak-kanak diperlukan untuk perkembangan kemahiran Matematik pada masa hadapan (Linder, Powers-Costello \& Stegelin, 2011; Hunting, Mousley \& Perry, 2012). Pendidikan awal adalah penting sebagai pelaburan dalam modal insan (Arteaga et al., 2014).

Kajian Hewitt (1994) ada membincangkan tentang pendidikan prasekolah di Malaysia kira-kira 25 tahun yang lalu. Beliau mendapati bahawa guru besar dan guru-guru memfokuskan kepada kemahiran 3M, guru besar menyatakan bahawa kurikulum yang berasaskan kepada bermain dilihat sebagai kurang 
digemari oleh kebanyakan ibu bapa di Malaysia dan keadaan sedemikian memberikan tekanan kepada guru untuk menyediakan program akademik yang formal. Selain itu, dapatan Hewitt dan Maloney (2000) di Malaysia dalam pendidikan prasekolah menunjukkan walaupun ibu bapa percaya bahawa bermain adalah penting, tetapi ianya adalah sekadar untuk mengisi waktu transisi untuk pembelajaran formal.

Walaupun jumlah wang yang banyak telah dilaburkan untuk memajukan pendidikan di Malaysia, prestasi pelajar dalam mata pelajaran Matematik telah menunjukkan kemerosotan. Penilaian TIMSS yang dilaporkan oleh Mullis, Martin, Foy dan Arora (2012) menunjukkan pencapaian mata pelajaran Matematik pelajar Malaysia menurun dari skor min purata 500 mata pada tahun 1999 dan 2003 kepada 440 mata pada tahun 2011. Dalam penilaian antarabangsa PISA yang dijalankan oleh OECD, dianggarkan hanya $56 \%$ daripada pelajar berumur 15 tahun mencapai penguasaan tahap minimum dalam membaca manakala hanya $41 \%$ dan $57 \%$ masing-masing dalam penguasaan peringkat asas mata pelajaran Matematik dan Sains (Walker, 2011). Laporan Mullis et al. (2012) dan Walker (2011) menunjukkan Malaysia perlu meningkatkan pencapaian mata pelajaran Matematik.

Menurut Gifford (2004) dan Fischetti (2013), ramai kanak-kanak melalui pengalaman sukar dalam matematik awal disebabkan kaedah mengajar untuk membantu kanak-kanak belajar tidak diketahui dengan jelas. Ini selaras dengan sangat sedikit kajian yang dijalankan tentang cara yang efektif dalam pengajaran mata pelajaran Matematik (Rohaty, 2012; Gifford, 2004) sedangkan kanak-kanak dilahirkan sebagai pemikir Matematik (Baroody, 1987; Geist, 2009; Wynn, 1992; Palmer \& Baroody, 2011; Starkey et al., 1990). Smith (2006) menyatakan mata pelajaran Matematik sukar dipelajari tetapi pendekatan pengajaran yang berpotensi diperlukan untuk membaiki pencapaian semua kanak-kanak di peringkat awal (Clarke, Baker \& Chard, 2007; Doabler et al., 2011). Mencari kaedah terbaik untuk mengajar Matematik merupakan cabaran dalam pendidikan mata pelajaran Matematik (Nafisah \& Zulkarnain, 2012). Kajian ini menggunakan kaedah permainan, buku nombor dan lembaran kerja yang dibina oleh penyelidik untuk mengenal pasti kesannya terhadap pencapaian matematik awal. Kaedah permainan dipilih kerana kepentingan belajar melalui bermain (KPM, 1999, 2003, 2010;2017).

\section{Objektif Kajian}

Kajian ini ialah Penggunaan kaedah permainan, buku nombor dan lembaran kerja dalam pembelajaran matematik awal dalam kalangan kanak-kanak prasekolah kebangsaan di daerah Tuaran, Sabah. Ia dikaji melalui objektif berikut:

i. Mengenal pasti tahap pencapaian matematik awal selepas intervensi dalam kalangan kanakkanak prasekolah kebangsaan di daerah Tuaran, Sabah.

ii. Mengenal pasti dan membandingkan perbezaan pencapaian Matematik awal antara kanakkanak prasekolah yang mengikuti kaedah permainan, buku nombor dan lembaran kerja.

iii. Mengenal pasti dan membandingkan perbezaan min markah pencapaian matematik awal antara kanak-kanak prasekolah yang mengikuti kaedah permainan, buku nombor dan lembaran kerja dengan mengawal markah Matematik sebelum intervensi.

\section{Soalan Kajian}

Selaras dengan objektif kajian yang telah dinyatakan, soalan-soalan kajian dinyatakan seperti berikut:

i. Apakah tahap pencapaian matematik awal dalam kalangan kanak-kanak prasekolah kebangsaan di daerah Tuaran, Sabah, selepas program intervensi dijalankan?

ii. Adakah terdapat perbezaan dalam pencapaian matematik awal antara kanak-kanak prasekolah yang mengikuti kaedah permainan, buku nombor

iii. Adakah terdapat perbezaan yang signifikan pada min markah pencapaian matematik awal antara kanak-kanak prasekolah yang mengikuti kaedah permainan, buku nombor dan lembaran kerja dengan mengawal markah Matematik sebelum intervensi? 


\section{Hipotesis Kajian}

$\mathrm{H}_{\mathrm{o}} 1$ Tidak terdapat perbezaan dalam pencapaian matematik awal antara kanak-kanak prasekolah yang mengikuti kaedah permainan, buku nombor dan lembaran kerja.

$\mathrm{H}_{\mathrm{o}} 2$ Tidak terdapat perbezaan yang signifikan pada min markah pencapaian matematik awal antara kanak-kanak prasekolah yang mengikuti kaedah permainan, buku nombor dan lembaran kerja dengan mengawal markah Matematik sebelum intervensi

\section{Sorotan Kajian}

\section{Teori Berkaitan Pemikiran Matematik}

Pembelajaran nombor bermula dari operasi pengiraan yang paling asas (Chin, 2013). Fokus pada peringkat ini bermula dengan kemahiran mengenal, membilang dan mengira angka-angka pada kuantiti yang lebih kecil (Griffin, Case \& Siegler, 1994). Baroody (1987) menyatakan bahawa pembelajaran matematik awal dalam kalangan kanak-kanak berdasarkan kepada konsep perkembangan beransur-ansur yang melibatkan sesuatu penemuan dan pembinaan makna yang lebih mendalam tentang angka dan konsep-konsep pengiraan. Penguasaan pengiraan asas membolehkan kanak-kanak menggunakan nombor dengan bebas bagi tujuan operasi berbeza (seperti operasi bahagi dan darab) tanpa perlu untuk sentiasa membuat penghitungan (Chin, 2013). Kanak-kanak mula mengembangkan kemampuan penaakulan sebelum mereka memulakan persekolahan formal (Doig \& Ompok 2010).

\section{Kaedah Mengajar}

Kurikulum pendidikan awal kanak-kanak mengutamakan Permainan sebagai asas dalam pembelajaran seseorang. Sandberg dan Vuorinen (2008:136) menyatakan bermain sebagai aktiviti terpenting dan permainan yang melibatkan pembinaan, peranan bermain dan pergerakan seharusnya dititikberatkan dalam pembelajaran kanak-kanak. Permainan mempunyai potensi memberi motivasi dan berlaku dalam konteks sosial yang bermakna (Ainley, 1990). Penulisan tentang buku bergambar memfokuskan kepada cerita dan ilustrasi gambar. Loughrey (2001) menyatakan guru perlu menggunakan buku besar sebagai satu kaedah mengajar yang berpotensi untuk membantu kanak-kanak belajar. Guru perlu berhati-hati ketika memilih buku banyak buku tidak sesuai dan berkemungkinan buku-buku tersebut tidak dibacakan kepada kanak-kanak (Manning \& Kirkland, 2012). Sperling dan Head (2002) mencadangkan agar guru membacakan buku setiap hari iaitu lima kali seminggu kepada kanak-kanak. Beberapa penyelidik seperti Ramson dan Manning (2013), Grossman (1996), Clements (2001), Kohn (2011), Burts et al. (1992), Kamii dan Rummelsburg (2008) dan Wien (2002) menyatakan bahawa Lembaran kerja tidak bersesuaian untuk kanak-kanak. Mereka berpendapat bahawa amat perlu untuk memberikan pengalaman pembelajaran yang menyeronokkan kepada kanak-kanak melalui suasana bermain. Kanakkanak mempunyai kebolehan komunikasi dengan baik, mempunyai pemikiran yang kreatif, daya imaginasi dan juga mempunyai kebolehan untuk menyelesaikan masalah (Brock, Sylvia, Jarvis \& Olusoga, 2009). Para pendidik perlu mengambil peluang mendidik kanak-kanak melalui kaedah yang dapat memaksimumkan sepenuhnya potensi mereka. Berbanding dengan penggunaan lembaran kerja, aktiviti bermain yang dilaksanakan dalam pembelajaran kanak-kanak adalah lebih baik (Kamii \& Yasuhiko, 2006).

Ringkasnya, ramai penyelidik bersetuju bahawa penggunaan permainan dapat meningkatkan pencapaian mata pelajaran Matematik dalam kalangan kanak-kanak (Ompok, Ling, Abdullah, Tambagas, Tony \& Said, 2020; Ompok \& Bacotang, 2019; Ling, Pang, Ompok, 2018; Ompok, Mei Teng \& Sapirai 2021; Ompok et al., 2018; Ompok, Doig \& Tambagas 2019; Stannard et al., 2001; Ramani \& Siegler, 2008; Peters, 1998; Luo et al., 2007; Wolfgang et al., 2003; Wilson et al., 2009; Siegler, 2009; Rizi et al., 2011; Ramani et al., 2012; Azila et al., 2011; Zakiah et al., 2013). Chen dan McNamee (2011) menyatakan bahawa permainan merupakan kaedah yang positif dalam meningkatkan pencapaian. Kanak-kanak yang diberi peluang bermain mempunyai tujuan yang jelas, menggunakan bahan untuk menyelesaikan masalah dan memerlukan tindakan untuk mencapai matlamat, memberi peluang kanak- 
kanak menghubungkaitkan bahan-bahan permainan dan menyediakan ruang kepada kanak-kanak berimaginasi (Ompok et al., 2020). Menurut kajian Thorell et al. (2009) yang menggunakan kesan latihan dan pemindahan fungsi eksekutif dalam kanak-kanak prasekolah, mereka mendapati bahawa bermain permainan yang berulang-ulang boleh meningkatkan ingatan kanak-kanak yang sedang bekerja.

Ringkasnya, kajian lepas memberi tumpuan kepada penggunaan buku kanak-kanak untuk mengajar Matematik namun belum banyak bukti empirikal dalam negara menggunakan kanak-kanak prasekolah sebagai responden. Lebih-lebih lagi, tidak terdapat kajian yang serupa dalam negara di peringkat yang sama. Daripada kajian empirikal terdahulu yang dijalankan oleh Jennings et al. (1992), Hong (1996), Tare et al. (2010) dan Casey et al. (2008), kaedah mengajar menggunakan buku nombor dijangka menunjukkan kesan yang signifikan terhadap pencapaian matematik awal.

\section{Pencapaian Matematik Awal}

Mengikut Mix et al. (2002), fasa pemikiran Matematik dibahagikan kepada tiga fasa yang merangkumi fasa pra pengiraan (precounting phase), fasa pengiraan (counting phase) dan fasa ketiga ialah simbol yang bertulis (written number phase). Menurut Ginsburg dan Baroody (2003), fasa pra pemikiran awal mulanya tidak menggunakan perkataan untuk berfikir tentang sesuatu himpunan dan bagaimana perubahan berlaku tetapi mereka mungkin menggunakan gambaran mental. Kanak-kanak boleh mengira himpunan objek dengan tepat, boleh membina kefahaman asas nombor dan operasi penambahan dan penolakan walaupun sebelum memasuki sekolah. Kanak-kanak dalam lingkungan tiga setengah tahun boleh mengingat dan menghasilkan semula himpunan objek dari satu hingga empat objek tanpa mengira. Pada usia tiga setengah hingga lima tahun, mereka boleh menunjukkan jumlah atau perbezaan apabila suatu bilangan item yang kecil ditambah atau ditolakkan dari objek sebelumnya yang dilihat. Menurut mereka lagi, kanak-kanak boleh menyelesaikan masalah penambahan dan penolakan yang mudah secara bukan lisan sebelum mereka berjaya melaksanakan masalah berbentuk cerita ataupun tugasan berbentuk simbolik seperti $2+1=$ ?. Dalam fasa pengiraan, Mix et al. (2002) menyatakan bahawa kanak-kanak boleh menyatakan nombor secara lisan semasa mengira dalam perkataan (counting words). Apabila keupayaan Matematik kanak-kanak berkembang, mereka boleh menamakan koleksi nombor yang lebih besar daripada empat dan melakukan operasi terhadap nombor-nombor ini. Ginsburg dan Baroody (2003) menyatakan bahawa fasa nombor bertulis berkemungkinan dapat membantu kanakkanak untuk berfikir dan mengoperasikan nombor yang lebih besar.

Gelman dan Gallistel (1978) berpendapat bahawa pemikiran kanak-kanak adalah konkrit dan abstrak. Bukan sahaja kanak-kanak boleh tambah tiga ekor anjing mainan dengan empat ekor anjing mainan untuk mendapatkan jumlah, mereka juga mempunyai idea yang abstrak dalam mengira termasuklah prinsip yang abstrak seperti peraturan mengira beberapa objek diskret. Mengikut Brush (1978), kanakkanak memahami idea asas tentang penambahan dan penolakan sejak di awal usia lagi. Kajian yang dijalankan oleh Wynn (1992) telah membuktikan kebolehan itu.

Ginsburg dan Baroody (2003) menyatakan bahawa pengetahuan Matematik kanak-kanak boleh dikategorikan sebagai tidak formal atau formal. Matematik tidak formal mewakili pengertian dan tatacara yang diperoleh di luar konteks persekolahan. Matematik formal mewakili kemahiran aritmetik dan konsep yang dipelajari oleh kanak-kanak di sekolah. Bagi Ginsburg dan Baroody (2003), kanakkanak sudah mempunyai konsep dan kemahiran yang tidak formal sebelum memasuki persekolahan. Situasi ini dipanggil sebagai tidak formal kerana mereka tidak belajar dalam konteks persekolahan yang formal. Kefahaman ini selalunya bersifat implisit. Seorang kanak-kanak berkemungkinan tidak berkebolehan untuk menerangkan mengapa dia menggunakan sesuatu strategi tidak formal atau mengapa jawapannya adalah munasabah. Konsep dan kemahiran ini diperoleh dalam pelbagai cara. Satu caranya ialah inisiatif oleh kanak-kanak itu sendiri atau interaksi dengan persekitaran mereka. Sebagai contoh, ibu memberitahu anak-anak bahawa setiap kumpulan yang mempunyai tiga orang kanak-kanak mestilah mempunyai jumlah gula-gula yang sama. Terdapat sebanyak sepuluh biji gula-gula yang harus dibahagikan kepada tiga orang kanak-kanak. Maka dalam aktiviti ini, kanak-kanak berpeluang untuk mempelajari konsep lebih, kurang atau sama banyak. Mereka juga akan mengambil inisiatif mengira himpunan untuk menghasilkan jumlah gula-gula yang sama dengan melibatkan aktiviti menambah atau menolak dengan menggunakan kemahiran yang tidak formal. 
Dalam pengetahuan Matematik formal, Ginsburg dan Baroody (2003) menyatakan kanak-kanak diajar dengan nombor dan kemahiran aritmetik, termasuk simbol bertulis. Sebagai contoh, nombor 7 mewakili nombor, dan tanda + atau - mewakili operasi terhadap sesuatu nombor. Kanak-kanak mencuba untuk menguasai fakta nombor contohnya $7+3=10$.

Berbanding dengan pengetahuan yang tidak formal, Ginsburg dan Baroody (2003) menyatakan pengetahuan konsep formal memerlukan kefahaman yang eksplisit iaitu kanak-kanak seharusnya dapat menerangkan secara rasional tatacara dan memberikan justifikasi terhadap sesuatu jawapan. Kunci asas dalam mentaksir pengetahuan formal adalah mengenal pasti sama ada kanak-kanak boleh menerangkan dan memberikan justifikasi tatacara secara eksplisit. Kebanyakan kanak-kanak terlepas peluang belajar tentang pengetahuan Matematik di luar konteks persekolahan kerana persekitaran yang kurang menyokong.

\section{Kesan Penggunaan Kaedah Lembaran Kerja Terhadap Pencapaian Matematik Awal Kanak-kanak}

Beberapa penyelidik pernah membincangkan tentang faktor yang mempengaruhi pencapaian. Dalam kajian yang dijalankan oleh Miller (1999) misalnya, beliau mendapati guru tertekan untuk mengajar secara formal berbanding main kerana nisbah guru dan murid yang besar (1:20 ataupun 1:40) serta tekanan dari ibu bapa dan keperluan menyediakan kanak-kanak mengikut kurikulum kebangsaan. Dapatan kajian Miller juga selaras dengan dapatan kajian terdahulu yang dijalankan oleh Evans dan Ismail (1995) dan masalah kekurangan bahan turut dilaporkan dalam kajian Evans dan Ismail (1995). Ringkasnya, dapatan kajian Hewitt (1994), Hewitt dan Maloney (2000), Miller (1999) serta Evans dan Ismail (1995) mendapati guru prasekolah kurang melaksanakan kurikulum kebangsaan melalui main walaupun pendekatan pengajaran dan pembelajaran di Malaysia adalah berasaskan kepada belajar melalui bermain.

Fuchs dan Wößman (2007) ada mengkritik nisbah guru dan murid. Mereka menyatakan bahawa sumber yang terhad di negara membangun sering membawa kepada prestasi akademik yang kurang baik kerana sekolah-sekolah usang, kekurangan guru dan kelas yang sesak. Keadaan ini boleh diatasi dengan proses pengajaran yang berkesan, menambahkan peralatan dan saiz kelas yang lebih kecil. Masalah nisbah guru dan murid yang tinggi boleh diatasi dengan pengajaran dan pembelajaran yang berkesan.

Tidak dapat disangkal lagi, kajian-kajian lepas telah membuktikan besarnya peranan pendidikan awal kanak-kanak. Sumbangan tokoh dalam bidang pendidikan awal telah mewarnai pengajaran dan pembelajaran dalam dunia kanak-kanak. Penyelidik lepas menekankan penggunaan permainan dalam membantu kanak-kanak meningkatkan pencapaian Matematik (Baroody, 1989; Baroody \& Coslick 1998; Baroody \& Wilkins, 1999; Piaget, 1962; Smilansky, 1968; Bragg, 2012; Sandberg \& Vuorinen, 2008; Barnett, 2011), literasi yang disepadukan dengan Matematik membantu dalam meningkatkan pencapaian Matematik (Whitin \& Wilde, 1992; McMath \& King, 1993; Shatzer, 2008; Jennings et al., 1992). Penggunaan kaedah lembaran kerja dipercayai boleh meningkatkan pencapaian kanak-kanak berdasarkan Katz (1987) dan kenyataan-kenyataan oleh Ransom dan Manning (2013), dan Dewey (1990). Katz (2013) menyatakan penggunaan lembaran kerja boleh meningkatkan pencapaian dalam jangka masa pendek. Ransom dan Manning (2013) bersetuju bahawa penggunaan lembaran kerja adalah memenuhi kehendak ibu bapa yang percaya bahawa anak-anak mereka belajar sekiranya ada membawa pulang lembaran kerja. Menurut Dewey (1990), penglibatan ibu bapa menyumbang kepada kejayaan sekolah.

\section{Metod Kajian}

\section{Reka Bentuk Kuasi Eksperimen}

Dalam kajian ini, penyelidik tidak dapat menggunakan prosedur perawakan (randomization) sepenuhnya. Ini disebabkan kelas prasekolah wujud dalam keadaan sedia ada. Mengikut Crowl (1993), 
kebanyakan penyelidikan dalam pendidikan tidak dapat memilih responden secara rawak untuk mengelakkan perubahan pada jadual waktu sekolah sedia ada dan mengubah kedudukan kanak-kanak dalam kelas. Oleh itu, reka bentuk kuasi eksperimen digunakan dalam keadaan pengagihan rawak tidak digunakan dalam proses pemilihan responden untuk penyelidikan (Noraini, 2013).

\section{Populasi dan Responden Kajian}

Dalam kajian ini, bilangan sampel yang mengikuti program intervensi ialah 1,108 orang. Pemilihan sampel minima berdasarkan kepada jadual Krejcie dan Morgan (1970) iaitu minimum 331 orang untuk setiap kaedah bagi populasi seramai 2500 orang. Mengikut Shaughnessy dan Zechneister (1990), kajian mempunyai kesahan luaran dalam reka bentuk kuasi eksperimen sekiranya dapatan boleh digeneralisasikan untuk satu populasi.

\section{Program Intervensi}

Sophian (2004) berpendirian bahawa adalah kritikal untuk mempertimbangkan bagaimana bahan pengajaran dipersembahkan kepada kanak-kanak kerana ianya memberi kesan kepada pembelajaran Matematik. Beberapa kajian rintis dilakukan dari semasa ke semasa bagi menguji kesesuaian ABM yang digunakan dalam kaedah mengajar iaitu permainan, buku nombor dan lembaran kerja. Bahan yang dipilih mengikut kaedah masing-masing adalah mengikut urutan yang terdapat dalam UPMA. Kemahiran matematik awal dalam Tunjang Sains dan Teknologi dalam KSPK menjadi rujukan dalam merancang aktviti mengikut kaedah mengajar untuk kajian ini. Kaedah pengajaran dibina dengan ciri yang dapat membantu mewujudkan pengalaman belajar yang konstruktif. Setiap aktiviti pada hari tertentu disusun agar menggunakan standard kandungan dan menjawab soalan yang sama. Ini bermakna semua kaedah di tiga kumpulan menggunakan bahan mengikut kaedah masing-masing, mempunyai standard kandungan Matematik yang sama dan menjawab soalan yang sama. Walau bagaimanapun, terdapat perbezaan dalam ubahsuaian permainan, tajuk buku baharu ataupun soalan penutup dalam kaedah buku nombor dan arahan soalan kaedah lembaran kerja. Perkara ini adalah untuk memastikan ketiga-tiga kaedah mengajar menggunakan kata tugas yang lebih kurang sama dengan soalan UPMA. Pengulangan bahan dalam kaedah buku nombor berlaku tetapi soalan penutup pada sesi pengajaran dan pembelajaran berbeza mengikut soalan UPMA. Penyelidik memperuntukkan masa sebanyak 15 hingga 30 minit selama 13 minggu semasa program intervensi dijalankan. Penggunaan kata-kata pujian dan galakan diberikan kepada kanak-kanak di sepanjang aktiviti dijalankan.

Mengikut Katz (1995:109), apa yang perlu dan bagaimana cara yang terbaik untuk kanak-kanak belajar adalah bergantung kepada pengetahuan guru tentang perkembangan kanak-kanak, kefahaman tentang pengalaman awal dan perkembangan seterusnya. Ransom dan Manning (2013) menegaskan bahawa guru kelas adalah pakar sebenar dalam menyediakan lembaran kerja dan ABM perlu mengikut budaya tempatan (Edwards \& Stern, 1969; Karnes et al., 1983; Stipek et al., 1998). Berdasarkan pengalaman penyelidik sebagai guru prasekolah di daerah Tuaran, perbincangan dengan pakar pendidikan awal kanak-kanak dan guru-guru prasekolah yang berpengalaman, penyelidik percaya bahawa bahan pengajaran yang dibina adalah merupakan aktiviti terbaik. Rujukan yang pelbagai adalah penting untuk memastikan kaedah mengajar yang dipilih memenuhi kriteria yang ditakrifkan dalam kajian ini.

\section{Alat Pengukuran}

Kajian ini menggunakan UPMA sebagai instrumen untuk mengumpul data yang digunakan dalam kajian ini. Cates (1990) mendefinisikan instrumen kajian sebagai alat yang digunakan untuk mengumpul data kajian berkaitan responden. Penyelidik telah membina dua set instrumen pencapaian matematik awal kanak-kanak prasekolah yang diadaptasikan daripada Test of Early Mathematics Ability (TEMA) (Ginsburg \& Baroody, 2003) berdasarkan KSPK. Instrumen ini merupakan ujian pra dan ujian pasca yang digunakan untuk membandingkan kesan daripada ketiga-tiga kaedah mengajar. Data-data penyelidikan diperoleh melalui kaedah temu bual dan pemerhatian tulisan kanak-kanak yang seterusnya diterjemahkan kepada data kuantitatif.

\section{Hasil Kajian}




\section{Tahap Pencapaian Matematik Awal}

Jadual 1 memaparkan maklumat pencapaian matematik awal kanak-kanak prasekolah dalam kajian ini. Tiga tahap pencapaian iaitu di bawah purata, purata dan atas purata. Min skor pada tahap bawah purata berada dalam lingkungan 0-60, min skor pada tahap purata berada dalam lingkungan 60-80 dan min skor pada tahap atas purata berada dalam lingkungan 80-100. Skor min kanak-kanak dalam kajian ini ialah 68.07 dengan sisihan piawai 21.44. Ini menunjukkan pencapaian matematik awal kanak-kanak dalam kajian ini selepas program intervensi dijalankan berada pada tahap purata.

Jadual 1: Statistik deskriptif pencapaian matematik awal kanak-kanak prasekolah

\begin{tabular}{llll}
\hline Pemboleh ubah & Bilangan & Min & Sisihan piawai \\
\hline Pencapaian matematik awal & 1108 & 68.07 & 21.44 \\
\hline
\end{tabular}

\section{Adakah Terdapat Perbezaan Dalam Pencapaian Matematik Awal Antara Kanak- kanak Prasekolah Yang Mengikuti Kaedah Permainan, Buku Nombor dan Lembaran Kerja?}

Ho1 Tidak terdapat perbezaan dalam pencapaian matematik awal antara kanak-kanak prasekolah yang mengikuti kaedah permainan, buku nombor dan lembaran kerja.

Jadual 2 memaparkan keputusan statistik deskriptif bagi $\mathrm{H}_{0} 1$. Keputusan statistik deskriptif menunjukkan nilai min pencapaian matematik awal bagi kaedah permainan mengatasi kedua-dua kaedah mengajar yang lain (min pencapaian matematik awal: kaedah permainan $=73.04$, buku nombor $=64.34$, lembaran kerja $=66.49)$.

Jadual 2 : Statistik deskriptif bagi $\mathrm{H}_{0} 1$

\begin{tabular}{llll}
\hline Kaedah mengajar & Bilangan & Min & Sisihan piawai \\
\hline Permainan & 382 & 73.04 & 21.39 \\
Buku Nombor & 349 & 64.34 & 20.47 \\
Lembaran Kerja & 377 & 66.49 & 21.47 \\
Jumlah & 1108 & 68.07 & 21.44 \\
\hline
\end{tabular}

Dependent Variable: UPASCA

Jadual 3 memaparkan keputusan Levene's Test of Equality of Error Variances ${ }^{\mathrm{a}}$ untuk $\mathrm{H}_{\mathrm{o}} 1$. Ujian Levene menguji hipotesis bahawa ralat varians pembolehubah bersandar bagi setiap kumpulan dalam pembolehubah tidak bersandar adalah sama. Keputusan ujian Levene bagi $\mathrm{H}_{0} 8$, iaitu $[\mathrm{F}(2,1105)=.14$, $\mathrm{p}>.05]$.

Jadual 3: Levene's Test of Equality of Error Variances ${ }^{\mathrm{a}}$ bagi $\mathrm{H}_{\mathrm{o}} 1$

\begin{tabular}{llll}
\hline F & df1 & df2 & Sig. \\
\hline .14 & 2 & 1105 & .87 \\
\hline
\end{tabular}

Dependent Variable: UPASCA

Tests the null hypothesis that the error variance of the dependent variable is equal across groups.

a. Design: Intercept + Kaedah mengajar

Jadual 4 memaparkan keputusan tests of between-subjects effects bagi $\mathrm{H}_{0} 1$. Keputusan ujian ANOVA sehala menunjukkan bahawa secara keseluruhan perbezaan pencapaian matematik awal antara ketigatiga kumpulan kaedah mengajar adalah signifikan $[\mathrm{F}(2,1105)=17.04, \mathrm{p}<.05]$. Berdasarkan keputusan ini, hipotesis nul ditolak. 
DOI: https://doi.org/10.47405/mjssh.v6i10.1117

\begin{tabular}{llllll}
\hline Source & Type III Sum of Squares & Df & Mean Square & F & Sig. \\
\hline Corrected Model & $15222.71^{\mathrm{a}}$ & 2 & 7611.35 & 17.04 & .00 \\
Intercept & 5108397.55 & 1 & 5108397.55 & 11437.52 & .00 \\
Kaedah mengajar & 15222.71 & 2 & 7611.35 & 17.04 & .00 \\
Error & 493531.58 & 1105 & 446.64 & & \\
Total & 5642487.50 & 1108 & & & \\
Corrected Total & 508754.29 & 1107 & & & \\
\hline
\end{tabular}

Dependent Variable: UPASCA

a. $\mathrm{R}$ Squared $=.030($ Adjusted R Squared $=.028)$

Jadual 5 memaparkan Pairwise Comparisons bagi $\mathrm{H}_{0} 8$. Keputusan perbandingan pasangan (Pairwise Comparisons) dengan mengawal ralat jenis 1 menggunakan kaedah Bonferroni. Ini menunjukkan bahawa nilai min pencapaian matematik awal bagi kaedah mengajar bagi pasangan min kaedah permainan dan buku nombor (perbezaan $\min =8.70, \mathrm{p}<.05$ ) adalah berbeza secara signifikan. Nilai min pencapaian matematik awal bagi kaedah mengajar bagi pasangan min kaedah permainan dan lembaran kerja (perbezaan min $=6.55, \mathrm{p}<.05$ ) adalah berbeza secara signifikan. Nilai min pencapaian matematik awal bagi kaedah mengajar bagi pasangan min kaedah buku nombor dan lembaran kerja (perbezaan min=-2.14, p>.05) adalah tidak berbeza secara signifikan. Ini bermakna bahawa perbezaan secara keseluruhan pencapaian matematik awal adalah disebabkan oleh perbezaan antara pasangan kaedah permainan dan buku nombor, dan kaedah permainan dan lembaran kerja.

Jadual 5: Pairwise Comparisons bagi $\mathrm{H}_{0} 1$

\begin{tabular}{lllll}
\hline $\begin{array}{l}\text { (I) Kaedah } \\
\text { mengajar }\end{array}$ & $(\mathbf{J})$ Kaedah mengajar & $\begin{array}{l}\text { Mean Difference (I- } \\
\text { J) }\end{array}$ & Std. Error & Sig. \\
\hline Permainan & Buku Nombor & $8.70^{*}$ & 1.57 & .00 \\
& Lembaran Kerja & $6.55^{*}$ & 1.53 & .00 \\
Buku Nombor & Permainan & $-8.70^{*}$ & 1.57 & .00 \\
\multirow{2}{*}{ Lembaran Kerja } & Lembaran Kerja & -2.14 & 1.57 & .52 \\
& Permainan & $-6.55^{*}$ & 1.53 & .00 \\
& Buku Nombor & 2.14 & 1.57 & .52 \\
\hline
\end{tabular}

Dependent Variable: UPASCA

Based on estimated marginal means

*. The mean difference is significant at the .05 level.

b. Adjustment for multiple comparisons: Bonferroni.

Jadual 6 menunjukkan Univariate Tests bagi $\mathrm{H}_{0} 1$ yang mengesahkan keputusan dalam jadual Pairwise Comparison bahawa terdapat pasangan perbandingan yang memperoleh keputusan yang signifikan.

Jadual 6 : Univariate Tests bagi $\mathrm{H}_{0} 1$

\begin{tabular}{llllll}
\hline & Sum of Squares & df & Mean Square & F & Sig. \\
\hline Contrast & 15222.71 & 2 & 7611.35 & 17.04 & .00 \\
Error & 493531.58 & 1105 & 446.64 & & \\
\hline
\end{tabular}

Dependent Variable: UPASCA

The F tests the effect of Kaedah mengajar. This test is based on the linearly independent pairwise comparisons among the estimated marginal means.

Adakah Terdapat Perbezaan Yang Signifikan Pada Min Markah Pencapaian Matematik Awal Antara Kanak-kanak Prasekolah Yang Mengikuti Kaedah Permainan, Buku Nombor dan Lembaran Kerja Dengan Mengawal Markah Matematik Sebelum Intervensi? 
$\mathrm{H}_{\mathrm{o}} 2$ Tidak terdapat perbezaan yang signifikan pada min markah pencapaian matematik awal antara kanak-kanak prasekolah yang mengikuti kaedah permainan, buku nombor dan lembaran kerja dengan mengawal markah Matematik sebelum intervensi.

Jadual 7 memaparkan keputusan Levene's Test of Equality of Error Variances ${ }^{a}$ bagi $\mathrm{H}_{0} 2$. Keputusan ujian Levene iaitu $[F(2,1105)=2.62, p>.05]$ adalah tidak signifikan. Ini menunjukkan bahawa tidak ada perbezaan varians dalam pemboleh ubah bersandar merentasi setiap kategori pemboleh ubah tidak bersandar. Data kajian mematuhi syarat ujian ANCOVA.

Jadual 7: Levene's Test of Equality of Error Variances ${ }^{a}$ bagi $\mathrm{H}_{0} 2$

\begin{tabular}{llll}
\hline $\mathrm{F}$ & $\mathrm{df} 1$ & $\mathrm{df} 2$ & Sig. \\
\hline 2.62 & 2 & 1105 & .07 \\
\hline
\end{tabular}

Dependent Variable: UPASCA

Tests the null hypothesis that the error variance of the dependent variable is equal across groups.

a. Design: Intercept + UPRA + Kaedah

Jadual 8 memaparkan keputusan statistik deskriptif bagi $\mathrm{H}_{\mathrm{o}} 2$. Keputusan statistik deskriptif memaparkan keputusan bahawa nilai min pencapaian matematik awal bagi kaedah permainan mengatasi kedua-dua kaedah mengajar yang lain (min pencapaian matematik awal: kaedah permainan $=73.04$, buku nombor $=64.34$, lembaran kerja $=66.49)$.

Jadual 8: Statistik deskriptif bagi $\mathrm{H}_{\mathrm{o}} 2$

\begin{tabular}{llll}
\hline Kaedah mengajar & Bilangan & Min & Sisihan piawai \\
\hline Permainan & 382 & 73.04 & 21.39 \\
Buku Nombor & 349 & 64.34 & 20.47 \\
Lembaran Kerja & 377 & 66.49 & 21.47 \\
Jumlah & 1108 & 68.07 & 21.44 \\
\hline
\end{tabular}

Dependent Variable: UPASCA

Jadual 9 memaparkan keputusan Tests of Between-Subjects Effects bagi $\mathrm{H}_{\mathrm{o}} 2$. Keputusan ujian ANCOVA menunjukkan ada kesan utama pemboleh ubah tidak bersandar kaedah mengajar yang signifikan terhadap pemboleh ubah bersandar pencapaian matematik awal [F $(2,1104)=18.00, \mathrm{p}<.05]$. Keputusan menunjukkan terdapat kesan utama pemboleh ubah kawalan ujian pra yang signifikan terhadap pemboleh ubah bersandar pencapaian matematik awal $[\mathrm{F}(1,1104)=637.72, \mathrm{p}<.05]$. Keputusan ini menunjukkan bahawa dengan mengawal markah ujian pra responden kajian, kaedah mengajar mempengaruhi pencapaian matematik awal responden kajian secara signifikan. Berdasarkan keputusan ini, penyelidik menolak hipotesis nul.

Jadual 9 : Tests of Between-Subjects Effects bagi $\mathrm{H}_{0} 2$

\begin{tabular}{llccll}
\hline Source & Type III Sum of Squares & Df & Mean Square & F & Sig. \\
\hline Corrected Model & $195026.27^{\mathrm{a}}$ & 3 & 65008.76 & 228.76 & .00 \\
Intercept & 281192.87 & 1 & 281192.87 & 989.51 & .00 \\
UPRA & 179803.57 & 1 & 179803.57 & 632.72 & .00 \\
Kaedah & 10232.13 & 2 & 5116.07 & 18.00 & .00 \\
Error & 313728.02 & 1104 & 284.17 & & \\
Total & 5642487.50 & 1108 & & & \\
Corrected Total & 508754.29 & 1107 & & & \\
\hline
\end{tabular}

Dependent Variable: UPASCA

a. R Squared $=.383($ Adjusted R Squared $=.382$ ) 
Jadual 10 memaparkan keputusan Pairwise Comparisons bagi $\mathrm{H}_{0} 2$. Keputusan ujian perbandingan pasangan markah pencapaian matematik awal bagi kaedah mengajar menunjukkan bahawa selepas mengawal ralat jenis 1 dengan menggunakan kaedah Bonferroni, pasangan perbandingan permainan buku nombor (perbezaan min pencapaian matematik awal=6.17, $\mathrm{p}<.05$ ) dan permainan- lembaran kerja (perbezaan min pencapaian matematik awal=6.59, $\mathrm{p}<.05$ ) memperoleh keputusan yang signifikan. Ini menunjukkan min markah pencapaian matematik awal bagi kaedah permainan mengatasi buku nombor dan lembaran kerja secara signifikan. Perbandingan pasangan buku nombor - lembaran kerja (perbezaan min pencapaian matematik awal=-0.43, p>.05) memperoleh perbezaan yang tidak signifikan kerana tidak terdapat perbezaan yang signifikan kesan antara buku nombor dan lembaran kerja.

Jadual 10: Pairwise Comparisons bagi $\mathrm{H}_{\mathrm{o}} 2$

\begin{tabular}{lllll}
\hline $\begin{array}{l}\text { Kaedah mengajar } \\
\text { Kandan }\end{array}$ & $\begin{array}{l}\text { (J) } \\
\text { Kaedah mengajar }\end{array}$ & $\begin{array}{l}\text { Mean Difference } \\
(\mathbf{I}-\mathbf{J})\end{array}$ & Std. Error & Sig. \\
\hline Permainan & Buku nombor & $6.17^{*}$ & 1.25 & .00 \\
& Lembaran kerja & $6.59^{*}$ & 1.22 & .00 \\
Buku Nombor & Permainan & $-6.17^{*}$ & 1.25 & .00 \\
& Lembaran kerja & .43 & 1.26 & 1.00 \\
Lembaran Kerja & Permainan & $-6.59^{*}$ & 1.22 & .00 \\
& Buku nombor & -.43 & 1.26 & 1.00 \\
\hline
\end{tabular}

Dependent Variable: UPASCA

Jadual 11 memaparkan keputusan Univariate Tests bagi $\mathrm{H}_{0} 2$. Keputusan dalam ujian Univariate Tests menunjukkan secara keseluruhan ada perbezaan yang signifikan bagi keputusan perbandingan pasangan $[\mathrm{F}(2,1104)=18.00, \mathrm{p}<.05]$. Keputusan ini mengesahkan terdapat kesan utama pemboleh ubah tidak bersandar kaedah mengajar terhadap pemboleh ubah bersandar pencapaian matematik awal, selepas mengawal pemboleh ubah kawalan ujian pra dalam populasi kajian.

Jadual 11 : Univariate Tests bagi $\mathrm{H}_{\mathrm{o}} 2$

\begin{tabular}{llllll} 
& Sum of Squares & Df & Mean Square & F & Sig. \\
\hline Contrast & 10232.13 & 2 & 5116.07 & 18.00 & .00 \\
Error & 313728.02 & 1104 & 284.17 & & \\
\hline Dep & & &
\end{tabular}

Dependent Variable: UPASCA

The $\mathrm{F}$ tests the effect of Kaedah mengajar. This test is based on the linearly independent pairwise comparisons among the estimated marginal means.

\section{Kesimpulan}

Tahap pencapaian matematik awal dalam kalangan kanak-kanak prasekolah kebangsaan di daerah Tuaran, Sabah berada pada tahap purata. Hasil kajian ini mendapati bahawa min markah pencapaian matematik awal adalah lebih rendah daripada dapatan kajian yang dijalankan oleh Rohaty (2012) yang menunjukkan bahawa pencapaian matematik awal berada pada atas purata. Keadaan ini mungkin disebabkan perbezaan seperti ciri demografi, ujian pencapaian yang berbeza dan sebagainya. Sememangnya setiap kanak-kanak normal dapat memahami konsep Matematik dengan baik jika diberi aktiviti mengikut kurikulum yang sesuai, kaedah mengajar yang melibatkan minat kanak-kanak dan latihan guru yang sama seperti yang dinyatakan oleh Rohani et al. (2004), terdapat faktor munasabah yang mungkin menyebabkan mengapa pencapaian matematik awal keseluruhan 1108 orang kanakkanak prasekolah yang menjadi responden dalam kajian ini hanya berada pada tahap purata. Hal ini berkemungkinan disebabkan oleh nisbah antara guru dan kanak-kanak adalah tinggi di Malaysia seperti yang dilaporkan oleh Miller (1999) serta Evans dan Ismail (1995). Pada tahun 2011, nisbah guru-kanakkanak prasekolah ialah (1:24) (Ekshibit 3-1) (KPM, 2012b). Keadaan ini menyukarkan guru untuk membantu dan memantau perkembangan setiap individu kanak-kanak secara terperinci. Selain itu, nilai sisihan piawai tinggi menunjukkan kemungkinan guru perlu mempelbagaikan kaedah mengajar. 
Pernyataan ini disokong oleh pandangan Matematik yang didukung oleh Dooley et al. (2014), semua kanak-kanak mempunyai keupayaan untuk menyelesaikan masalah, memahami dunia menggunakan Matematik dan berkomunikasi tentang Matematik. Perspektif ini dan dapatan kajian tentang tahap pencapaian matematik awal menuntut perubahan dalam pedagogi. Para guru harus terus berusaha menempuh cabaran dalam memajukan pendidikan awal kanak-kanak di Malaysia melalui pendekatan pencapaian.

Setelah tiga belas minggu program intervensi ini dijalankan, hasil daripada inisiatif penyelidik dan semua yang telah membantu dalam menjayakan kajian ini telah membuahkan kesan positif. Dapatan kajian ujian ANOVA satu hala, ANCOVA dan MANCOVA menunjukkan bahawa terdapat perbezaan yang signifikan pada min markah pencapaian matematik awal dalam kalangan kanak-kanak prasekolah yang mengikuti kaedah permainan, buku nombor dan lembaran kerja. Hasil kajian ini selaras dengan dapatan kajian-kajian terdahulu iaitu penggunaan permainan untuk meningkatkan pencapaian matematik awal (Stannard et al., 2001; Ramani \& Siegler, 2008; Peters, 1998; Ramani et al., 2012; Luo et al., 2007; Wolfgang et al., 2003; Wilson et al., 2009; Siegler, 2009; Azila et al., 2011; Zakiah et al., 2013), literatur dalam pengajaran Matematik bagi meningkatkan pencapaian Matematik (Casey et al., 2004; Jennings et al., 1992) dan kenyataan bahawa penggunaan lembaran kerja boleh meningkatkan pencapaian dalam jangka masa yang pendek (Katz, 1987).

Kesimpulannya, terdapat perbezaan min markah yang signifikan bagi pencapaian matematik awal bagi kaedah-kaedah yang berbeza. Berdasarkan dapatan kajian ini, guru dicadangkan menggunakan tiga kaedah dalam mengajar (permainan, buku nombor dan lembaran kerja). Kanak-kanak perlu diberi perhatian bagi mencapai aspirasi yang tinggi di tengah-tengah persekitaran global yang semakin berdaya saing.

\section{Rujukan}

Ainley, J. (1990). Playing games and learning Mathematics. In Steffe, L.P. and Wood, T. (eds.). Transforming children's Mathematics education: International perspectives, pp. 84-91. Hillsdale: Erlbaum.

Arteaga, I., Humpage, S., Reynolds, A.J. \& Temple, J.A. (2014). One year of preschool or two: Is it important for adult outcome? Economic of Education Review, 40, 221-237.

Azila Alias, Abd. Aziz Shukor \& Noor Aini Ahmad. (2011). The effectiveness of using games in teaching early numbers to kindergarten children. The International Conference on Early Childhood and Special Education (ICECSE) 2011. Basic Education Research Unit. School of Educational Studies. Universiti Sains Malaysia.

Barnett, W.S. (2011). Effectiveness of early educational intervention. Science, 333, 975-978.

Baroody, A.J. \& Wilkins, J.L.M. (1999). The development of informal counting, number, and arithmetic skills and concepts. In Copley, J.V. (eds.). Mathematics in the early years, pp. 48-65. Reston: National Council of Teachers of Mathematics.

Baroody, A.J. (1987). Children's Mathematical thinking: A developmental framework for preschool, primary, and special education teachers. New York: Teachers College Press.

Baroody, A.J. (2006). The development of young children's early number and operation sense and its implications of early childhood education. In Spodek, B. and Saracho, O.N. (eds.). Handbook of research on the education of young children ( $2^{\text {nd }}$ edition), pp. 187-221. Mahwah: Erlbaum.

Bragg, L.A. (2012). Testing the effectiveness of Mathematical games as a pedagogical tool for children's learning. International Journal of Science and Mathematics Education, 10(6), 14451467.

Brock, A., Sylvia, D. Jarvis, P. \& Olusoga, Y. (2009). Perspectives on play: Leaning for life. England: Pearson Education Limited.

Bruner, J.S. (1966). Toward a theory of instruction. Cambridge: Belknap.

Brush, L. R. (1978). Preschool children's knowledge of addition and subtraction. Journal for Research in Mathematics Education. 9:44-54.

Casey, B. (2004). Mathematics problem-solving adventures: A language-arts-based supplementary series for early childhood that focuses on spatial sense. In Clements, D. and Samara, J. (eds.). 
Engaging young children in Mathematics: Standards for early childhood Mathematics education, pp. 377-389. Mahwah: Lawrence Erlbaum.

Casey, B.M., Erkut, S., Ceder, I. \& Young, J.M. (2008). Use of a storytelling context to improve girl's and boy's geometry skills in kindergarten. Journal of Applied Developmental Psychology, 29, 2948.

Casey, B.M., Kersh, J.E. \& Young, J.M. (2004). Storytelling sagas: An effective medium for teaching early childhood Mathematics. Early Childhood Research Quarterly, 19, 167-172.

Cates, W.M. (1990). Panduan amali untuk penyelidikan pendidikan. Penterjemah: Syaharom Abdullah. Kuala Lumpur: Dewan Bahasa dan Pustaka.

Chard, D.F., Baker, S.K., Clarke, B., Jungjohann, K., Davis, K. \& Smolkowski, K. (2008). Preventing early Mathematics difficulties: The feasibility of a rigorous kindergarten Mathematics curriculum. Learning Disability Quarterly, 13, 11-20.

Chen, J.Q. \& McNamee, G.D. (2011). Positive approaches to learning in the context of preschool classroom activities. Early Childhood Education Journal, 39, 71-78.

Chin, K. E. (2013). Making sense of Mathematics : Supportive and problematics conceptions with special reference to trigonometry. A thesis submitted for the degree of Doctor of Philosophy. University of Warwick.

Clarke, B., Baker, S.K. \& Chard, D.J. (2007). Measuring number sense development in young children: A summary of early research. Leadership to Math Success for All, 5, 1-11.

Clements, D.H (2001). Mathematics in the preschool. Teaching Children Mathematics, 7, 270-275.

Clements, D.H. \& Sarama, J. (2011). Investing early in education: Early childhood Mathematics intervention. Science, 19(333), 968-970.

Crowl, T.K. (1993). Fundamentals of educational research. New York: Brown \& Benchmark Publishing.

Davis, R.B., Maher, C.A. \& Noddings, N. (1990). Constructivist Views on the Teaching and Learning of Mathematics. In Davis, R.B., Maher, C.A. and Noddings, N. (Eds.). Constructivist views on the teaching and learning Mathematics. Journal for Research in Mathematics Education. Monograf 4. Reston, VA: National Council of Teachers of Mathematics.

Dewey, J. (1990). The school and the society and the child and the curriculum. Combined Edition. Chicago: The University of Chicago Press.

Doabler, C., Baker, S.K., Smolkowski, K., Fien, H., Clarke, B., Cary, M.S. \& Chard, D. (2011). Impact and implementation analyses of the ELM kindergarten Mathematics intervention. SREE Spring 2012 Conference Abstract Template.

Doig, B., \& Ompok, C. (2010). Assessing young children's mathematical abilities through games. Procedia - Social and Behavioral Sciences, 8, 228-235. https://doi.org/10.1016/j.sbspro.2010.12.031.

Dooley, T., Dunphy, E., Shiel, G., Butler, D., Corcoran, D., Farrell, T., NicMhuiri, S., O’Connor, M., Travers, J. \& Perry, B. (2014). Mathematics in early childhood and primary education (3-8 years). Research Report Number 18. Dublin: National Council for Curriculum and Assessment.

Edwards, J. \& Stern, C. (1969). A comparison of three intervention programs with disadvantaged preschool children. Final report 1968-1969. Los Angeles: University of California Head Start Research and Evaluation Centre. (ERIC Document Reproduction Service No. ED 041616).

Evans, J.L. \& Ismail, K. (1995). Malaysian early childhood development study. Kuala Lumpur: Economic Planning Unit, Prime Minister's Department.

Fischetti, J.C. (2013). Issues in education: Last stand for teacher education. Childhood Education. 89(1):40-41.

Fuchs, T. \& Wößman, L. (2007). What accounts for international differences for student performance? A re-examination using PISA data. CESifo Working Paper. Empirical Economics, 32, 433-464.

Fullan, M. (1982). The meaning of educational change. London: Teachers College Press.

Geist, E. (2009). Children are born Mathematicians. Supporting Mathematical development, birth to age 8. Columbus: Pearson Education.Griffin, S., Case, R. and Siegler, R. 1994. Rightstart: Providing the central conceptual prerequisites for first formal learning of arithmetic to students atrisk for school failure. In McGilly, K. (Ed.). Classroom lessons: Integrating cognitive theory and classroom practice, pp. 24-49. Cambridge, MA: Bradford Books MIT Press.

Gifford, S. (2004). A new Mathematics pedagogy for the early years: In search of principles for practice. International Journal of Early Years Education, 12(2). 
Ginsburg, H.P. \& Baroody, A.J. (2003). Test of early Mathematics ability ( $3^{\text {rd }}$ edition) Austin: PRO-ED SAGE Publications.

Ginsburg, H.P. (1975). Young children's informal knowledge of Mathematics. Journal of Children's Mathematical Behavior, 1, 63-156.

Griffin, S., Case, R. \& Siegler, R. (1994). Rightstart: Providing the central conceptual prerequisites for first formal learning of arithmetic to students at-risk for school failure. In McGilly, K. (Ed.). Classroom lessons: Integrating cognitive theory and classroom practice, pp. 24-49. Cambridge, MA: Bradford Books MIT Press.

Hachey, A.C. (2013). The early childhood Mathematics education revolution. Early Education and Development, 24(4), 419-430.

Hewitt, B. \& Maloney, C. (2000). Malaysian parent's ideal and actual perceptions of pre-school education. International Journal of Early Years Education, 8(1), 83-92.

Hewitt, B.L. (1994). Pre-school education in Malaysia: An investigation into current practice. Unpublished paper. Edith Cowan University, Perth, Australia.

Hong, H. (1996). Effects of Mathematics learning through children's literature on Math achievement and dispositional outcomes. Early Childhood Research Quarterly, 11, 477-494.

Hunting, R., Mousley, J. \& Perry, B. (2012).Young children learning Mathematics: A guide for educators and families. Melbourne, Vic.: ACER press.

Jennings, C.M., Jennings, J.E., Richey, J. \& Dixon-Krauss, L. (1992). Increasing interest and achievement in Mathematics through children's literature. Early Childhood Research Quarterly, 7, 263-276.

Kamii, C. \& Rummelsburg, J. (2008). Arithmetic for first graders lacking number concepts. Teaching Children Mathematics, 14(7), 389-394.

Kamii, C. \& Yasuhiko, K. (2006). Play and mathematics at ages one to ten. In Fromberg, D. P. and Bergen, D. (Eds.). Play from Birth to Twelve (2nd ed.), pp. 187-198. New York: Taylor and Francis Group.

Karnes, M.B., Shwedel, A.M. \& Williams, M.B. (1983). A comparison of five approaches for educating young children from low-income homes. In Consortium for Longitudinal Studies (eds.). As the twig is bent: Lasting effects of preschool programs, pp. 133-179. Hillsdale: Erlbaum.

Katz, L.G. (1987). Early education: What should young children be doing? In Kagan, S.L. and Zigler, E.F. (eds.). Early Schooling: The National Debate, pp. 151-167. New Haven: Yale University Press.

Kementerian Pendidikan Malaysia. (1999). Kurikulum Pendidikan Prasekolah. Kuala Lumpur. Dewan Bahasa dan Pustaka.

Kementerian Pendidikan Malaysia. (2003). Kurikulum Prasekolah Kebangsaan. Kuala Lumpur. Dewan Bahasa dan Pustaka.

Kementerian Pendidikan Malaysia. (2010). Kurikulum Standard Prasekolah Kebangsaan. Kuala Lumpur: Bahagian Pembangunan Kurikulum.

Kementerian Pendidikan Malaysia. (2017). Kurikulum Standard Prasekolah Kebangsaan. Kuala Lumpur: Bahagian Pembangunan Kurikulum.

Kohn, A. (2011). Poor teaching for poor children . . . in the name of reform. Education Week. 30(29): 32-33.

Krejcie, R.V. \& Morgan, D.W. (1970). Determining sample size for research activities. Educational and Psychological Measurement, 30, 607-610.

Lee, J. S. \& Ginsburg, H.P. (2009). Early childhood teachers' misconceptions about Mathematics education for young children in the United States. Australasian Journal of Early Childhood, 34(4), 37-45.

Linder, S.M., Powers-Costello, B. \& Stegelin, D.A. (2011). Mathematics in early childhood:Researchbased rationale and practical strategies. Early Childhood Education Journal, 39, 29-37.

Ling MT., Pang V., \& Ompok C.C. (2018). Measuring Change in Early Mathematics Ability of Children Who Learn Using Games: Stacked Analysis in Rasch Measurement. In: Zhang Q. (eds) Pacific Rim Objective Measurement Symposium (PROMS) 2016 Conference Proceedings. Springer, Singapore. https://doi.org/10.1007/978-981-10-8138-5_17

Loughrey, D. (2001). The case for the use of big books in the early years classroom. Early Child Development and Care, 169(1), 85-96. 
Luo, Z., Jose, P.E., Huntsinger, C.S. \& Pigott, T.D. (2007). Fine motor skills and Mathematics achievement in East Asian American and European American kindergarten and first graders. British Journal of Developmental Psychology, 25, 595-614.

Manning, M. \& Kirkland, L. (2012). Books for children: Books that delight preschoolers. Childhood Education, 88(6), 400-403.

McMath, J. \& King, M. A. (1993). Using picture books to teach Mathematical concepts. Early Childhood Education Journal, 2(3),18-22.

Miller, L. (1999). Teaching and learning about play, language and literacy with preschool educators in Malaysia. International Journal of Early Childhood, 31(2), 55-56.

Mix, K.S., Huttenlocher, J. \& Levine, S.C. (2002). Quantitative development in infancy and early childhood. New York: Oxford University Press.

Mullis, V.S., Martin, M.O., Foy, P. \& Arora, A. (2012).TIMSS 2011 International results in Mathematics. International association for the evaluation of educational achievement. Chestnut Hill, MA: TIMSS \& PIRLS International Study Center, Boston College.

Nafisah@Kamariah Mohd. Kamaruddin \& Zulkarnain Mohd. Amin. (2012). Dilemma in teaching Mathematics. US-China Education Review, 145-149.

Nani Menon \& Rohani Abdullah. (2004). Panduan kognitif kanak-kanak prasekolah. Pahang: PTS Publications.

Noraini Idris. (2013). Penyelidikan dalam pendidikan. (Edisi Kedua) Kuala Lumpur: McGraw-Hill Education.

Ompok, C. S. (2015). Kesan penggunaan kaedah permainan, buku nombor dan lembaran kerja terhadap pencapaian awal Matematik dalam kalangan kanak-kanak prasekolah kebangsaan. Thesis Ijazah Doktor Falsafah UMS.https://scholar.google.com/citations?view op $=$ view citation $\&$ hl $=e n \& u s e r=B 5 X C K F 4 A A A$ AJ\&citation for view $=$ B5XCKF4AAAAJ:3fE2CSJIrl8C

Ompok, C. S., \& Bacotang, J. (2019). Kesan kaedah mengajar terhadap pencapaian awal matematik dalam kalangan kanak-kanak prasekolah. Jurnal Pendidikan Awal Kanak-Kanak Kebangsaan, 8, 8-16. https://doi.org/10.37134/jpak.vol8.2.2019

Ompok, C. S., Ling, M. T., Abdullah, S. N. M. @ S., Tambagas, M., Tony, E. E., \& Said, N. (2020). Mentor-mentee programme for STEM education at preschool level. Southeast Asia Early Childhood Journal,9(1), 1-14. https://ejournal.upsi.edu.my/index.php/SAECJ/article/view/3147

Ompok, C. S., Mei Teng, L., \& Sapirai, J. (2021). Effect of games towards children's mathematics performance. Southeast Asia Early Childhood Journal, 10(1), 1-17. https://doi.org/10.37134/saecj.vol10.1.1.2021

Ompok, C. S., Doig, B. \& Tambagas, M. (2019). Patterns of Young Children's Number Sense Development as Assessed by How Many Hidden Game. Journal of Cognitive Sciences and Human Development, 4(2).

Ompok, C. S., Teng, L., Pang, V., Mun, H., Abdullah, A., \& Sapirai, J. (2018). Early mathematics learning in reading and writing numerals: Learning through "What are the numbers?" A picture book made up of Flora and Fauna in Borneo. Southeast Asia Early Childhood Journal, 7, 52-59. https://doi.org/10.37134/saecj.vol7.6.2018

Parks, A.N. \& Bridges-Rhoads, S. (2012). Overly scripted: Exploring the impact of a scripted literacy curriculum on a preschool teacher's instructional practices in Mathematics. Journal of Research in Childhood Education, 26, 308-324.

Patterns of Young Children's Number Sense Development as Assessed by How Many Hidden Game | Journal of Cognitive Sciences and Human Development (unimas.my)

Peters, S. (1998). Playing games and learning Mathematics. The result of two intervention studies. International Journal of Early Years Education, 6(1), 49-58.

Piaget, J. (1962). Play, dreams and imitation in childhood. New York: W.W. Norton.

Ramani, G.B. \& Siegler, R.S. 2008. Promoting broad and stable improvements in low-income children's numerical knowledge through playing number board games. Child Development, 79(2),375-394.

Ramani, G.B., Hitti, A. \& Siegler, R.S. (2012). Taking it to the classroom: Number board games as a small group learning activity. Journal of Educational Psychology, 104(3), 661-672. 
Ransom, M. \& Manning, M. (2013). Teaching strategies: Worksheets, worksheets, and worksheets. Childhood Education, 89(3), 188-190.

Rizi, C.E., Gholami, A. \& Koulaynejad, J. (2011). The compare the affect instruction in experimental and practical approach (with emphasis on play) to verbal approach on Mathematics educational progress. Procedia Social and Behavioral Sciences, 15, 2192-2195.

Rohaty Mohd. Majzub. (2012). Preschool children's early Mathematics achievement based on gender and ethnicity. Asian Social Science, 8(16), 24-29.

Sandberg, A. \& Vuorinen, T. (2008). Dimensions of childhood play and toys. Asia-Pacific Journal of Teacher Education, 36(2),135-146.

Shatzer, J. (2008). Picture book power: Connecting children's literature and Mathematics. International Reading Association, 61(8), 649-653.

Shaughnessy, J.J. \& Zechmeister, E.B. (1990). Research methods in psychology. New York: McGraw Hill.

Shore, R. (1997)."What have we learned?" in “Rethinking the brain”, pp. 15-27. New York: Families and Work Institute.

Siegler, R.S. (2009). Improving the numerical understanding of children from low-income families. Child Development, 3, 118-124.

Skoumpourdi, C. \& Mpakopoulou, I. (2011). The prints: A picture book for pre-formal geometry. Early childhood Education Journal, 39, 197-206.

Smilansky, S. (1968). The effects of socio-dramatic play on disadvantaged preschool children. New York: Wiley.

Smith, S.S. (2006). Early Childhood Mathematics ( $3^{\text {rd }}$ edition). Boston: Allyn and Bacon.

Sophian, C. (2004). Mathematics for the future: Developing a Head Start curriculum to support Mathematics learning. Early Childhood Research Quarterly, 19, 59-81.

Sperling, R. A. \& Head, D. M. (2002). Reading attitudes and literacy skills in prekindergarten children. Early Childhood Education, 29(4), 233-236.

Stannard, L., Wolfgang, C.H., Jones, I. \& Phelps, P. 2001. A longitudinal study of the predictive relations among construction play and Mathematical achievement. Early Child Development and Care, 167(1), 115-125.

Stipek, D., Feiler, R., Byler, P., Ryan, R., Milburn, S. \& Salmon, J.M. 1998. Good beginnings: What differences does the program make in preparing young children for school? Journal of Applied Developmental Psychology, 19, 41-66.

Tare, M., Chiong, C., Ganea, P. \& DeLoache, J. 2010. Less is more: How manipulative features affect children's learning from picture books. Journal of Applied Developmental Psychology, 31, 395400.

Thorell, L., Lindqvist, S., Nutley, S., Bohlin, G. \& Klingbert, T. (2009). Training and transfer effects of executive functions in preschool children. Developmental Science, 12(1), 106-113.

Walker, M. (2011). "PISA 2009 plus results: Performance of 15-year olds in Reading, Mathematics and Science for 10 additional participants, http://acerpress.com.au". Retrived 01 Januari 2014.

Whitin, D. J. \& Wilde, S. (1992). Read any good Math lately? Children's books for Mathematical learning, K-6. In Shatzer, J. 2008. Picture Book Power: Connecting Children's Literature and Mathematics. International Reading Association, 61(8), 649-653.

Wien, C.A. (2002). The press of standardized curriculum: Does a kindergarten teacher instruct with worksheet or let them play? Canadian Children, 27(1), 10-17.

Wilson, A.J., Dehaene, S., Dubois, O. \& Fayol, M. (2009). Effects of an adaptive game intervention on accessing number sense in low-socioeconomic-status kindergarten children. Mind, Brain, and Education, 3, 224-234.

Wolfgang, C. H., Stannard,L.L. \& I. Jones, I. (2001). Block play performance among preschoolers as a predictor of later school achievement in Mathematics. Journal of Research in Childhood Education, 15(2), 173-180.

Wolfgang, C., Stannard, L. \& Jones, I. (2003). Advanced constructional play with LEGO among preschooler's as a predictor of later school achievement in Mathematics. Early Child Development and Care, 173(5), 467-475.

Wynroth, L. (1986). Wynroth Math program-The natural numbers sequence. In Baroody, A. J. and Coslick, R. T. 1998. Fostering children's Mathematical power: An investigative approach to K-8 Mathematics instruction. Mahwah: Lawrence Erlbaum Associates. 
Malaysian Journal of Social Sciences and Humanities (MJSSH), Volume 6, Issue 10, (page 235 - 251), 2021

DOI: https://doi.org/10.47405/mjssh.v6i10.1117

Zakiah, Azlina \& Yeo. (2013). Keberkesanan modul belajar terhadap pengalaman pranombor kanakkanak prasekolah. Proceedings: $2^{\text {nd }}$ International Seminar on Quality and Affordable Education, 7-10 Oktober, Johor Bahru. 